\title{
In vitro inhibition of acetylcholinesterase by crude plant extracts from Colombian flora
}

\author{
Jaime Niño ${ }^{+}$, Jimmy A Hernández, Yaned M Correa, Oscar M Mosquera \\ Grupo de Biotecnología-Productos Naturales, Escuela de Tecnología Química, Universidad Tecnológica de Pereira, A.A. 97, \\ Pereira, Risaralda, Colombia
}

The methanol extracts from five different plant families (Asteraceae, Euphorbiaceae, Melastomataceae, Rubiaceae, and Solanaceae) collected at Regional Natural Park Ucumari (Colombia), were screened for their acetylcholinesterase inhibitory activity through the modified Ellman's spectrophotometric method. The best inhibitory activities on this study were shown by the extracts of Solanum leucocarpum Dunal $\left(I C_{50}=204.59 \mathrm{mg} / \mathrm{l}\right)$ and Witheringia coccoloboides $($ Damm $)\left(I C_{50}=220.68 \mathrm{mg} / \mathrm{l}\right)$, both plants belonging to the Solanaceae family.

Key words: acetylcholinesterase (AChE) inhibitors - Asteraceae - Euphorbiaceae - Melastomataceae - Rubiaceae - Solanaceae

The acetylcholinesterase enzyme (AChE) is an attractive target for the rational drug design and for the discovery of mechanism based inhibitors because of its role in the hydrolysis of the neurotransmitter acetylcholine (ACh). AChE inhibitors are the most effective approach to treat the cognitive symptoms of Alzheimer disease (AD) (Kalauni et al. 2002, Atta-ur-Rahman et al. 2004) and other possible therapeutic applications in the treatment of Parkinson's disease, senile dementia, and ataxia, among others (Ahmad et al. 2003a). AChE inhibitors as eserine, tacrine, donepezil, rivastigmine, and galanthamine are the only drugs currently approved for the treatment of AD; however, these drugs are known to have limitations for clinical use due to their short-half-lives and/or unfavorable side-effects (Sung et al. 2002).

Because the search of plant extracts that selectively inhibit $\mathrm{AChE}$ is of paramount importance to find novel and more potent $\mathrm{AChE}$ inhibitors, many of them have been screened and as consequence there have been found extracts and isolated pure compounds with $\mathrm{AChE}$ and/or butyrylcholinesterase (BChE) inhibitory properties. Among the plant families that have been examined for their AChE inhibitory activity are: Amaryllidaceae (Houghton et al. 2004, Rhee et al. 2004), Boraginaceae (Ahmad et al. 2003b), Chenopodiaceae (Ferheen et al. 2005), Lamiaceae (Ahmad et al. 2005), Liliaceae (Atta-urRahman et al. 2002), and Solanaceae (Roddick 1989, Choudhary et al. 2004).

Continuing with the study of the flora from Regional Natural Park Ucumarí (RNPU, Risaralda, Colombia) as a source of new secondary metabolites with diverse grade of biological activities (Niño et al. 2003, 2006, Mosquera et al. 2004a) and the fact that there still is great interest in finding novel and better $\mathrm{AChE}$ inhibitors, prompted us to

\footnotetext{
Financial support: Universidad Tecnológica de Pereira ${ }^{+}$Corresponding author: janino@utp.edu.co

Received 25 May 2006

Accepted 23 August 2006
}

screen 27 crude methanol extracts belonging to the Asteraceae, Euphorbiaceae, Melastomataceae, Rubiaceae, and Solananceae families for their AChE inhibitory activities.

\section{MATERIALS AND METHODS}

In this study, the solvent hexanes, dichloromethane, and methanol (analytical-reagent grade) were purchased from Mallinckrodt (Phillipsburg, NJ, US). Silica gel plates (Silica gel $60 \mathrm{~F}_{254} 0.2 \mathrm{~mm}$ layer thickness) were purchased from Merck (Darmstadt, Germany). The electric eel acetylcholinesterase Sigma (St Louis, MO, US) was used. Acetylthiocholine iodide and 5,5-dithiobis (2-nitro benzoic acid) (DTNB) were purchased from Aldrich (St Louis, MO, US). A Spectronic Genesys 5 spectrophotometer Milton Roy (Rochester, NY, US) was used for all measurements of acetylcholinesterase inhibitory activity.

Plant material - Twenty seven plants from the selected families were collected at RNPU in February 2000 and October 2001, they were authenticated by Prof. FJ Roldán and are listed on the Table. Voucher specimens for each plant collected were deposited at University of Antioquia Herbarium (Medellín, Colombia).

The collected plant materials were worked out and extracted according to the procedure described by Niño et al. (2006).

In vitro acetylcholinesterase inhibition assay - In this work, 27 crude methanol plant extracts were examined for their AChE inhibitory activities at concentrations of 1000, 100 , and $10 \mathrm{mg} / \mathrm{l}$ and were dissolved in a base-tris $(0.05 \mathrm{M})$ buffer, following the spectrophotometric method developed by Ellman et al. (1961) as described by Salles et al. (2003). In this method, to a $1 \mathrm{~cm}$ path length glass cell, were added in order, $200 \mu$ l of acetylthiocholine iodide (15 $\mathrm{mM}), 1000 \mu \mathrm{l}$ of DTNB ( $3 \mathrm{mM})$, and $200 \mu 1$ of each test extract solution at the different concentrations evaluated, which were mixed and incubated for $15 \mathrm{~min}$ at $30^{\circ} \mathrm{C}$. Then, the mixture was monitored spectrophotometrically at 412 $\mathrm{nm} 10$ times, each $13 \mathrm{~s}$. After that, $200 \mu \mathrm{l}$ of AChE (0.3 U/ $\mathrm{ml}$ ) solution were added to the initial mixture, to start the reaction and then the absorbance was determined.

Control contained all components except the tested 
extract. As positive control eserine $(2.75 \mathrm{mg} / \mathrm{l})$ was used. The percentage of AChE inhibitory activity (\% IA) was calculated by using the following equation:

$$
\% \mathrm{IA}=[(\mathrm{Cc}-\mathrm{Ce}) / \mathrm{Cc}] \times 100
$$

where: $\mathrm{Cc}$ is the control kinetic (containing all reactants, except the AChE enzyme) and $\mathrm{Ce}$ is the experimental kinetic for each sample concentration. All treatments were performed in triplicate with two replicates.

Estimation of $I C_{50}$ values - The concentrations of the tested extracts that inhibited the hydrolysis of substrate (acetylthiocholine) by $50 \%\left(\mathrm{IC}_{50}\right)$ were determined by a linear regression analysis between the inhibition percentages against the extract concentrations by using the Excel program.

Phytochemical screening - For each plant extract a phytochemical screening was performed testing the presence of secondary metabolites by using TLC analyses. The solvent system was chloroform:ethyl acetate: methanol $(2: 2: 1)$, development was performed on aluminium plates coated with silica gel $60 \mathrm{~F}_{254}$. The following spray reagents were used in order to develop the spots: anisaldehyde-sulphuric acid (sterols), 1\% ferric chloride (tannins), 2\% aluminium chloride in ethanol (flavonoids),
$1 \%$ vainillin in sulphuric acid-ethanol (saponins), and Dragendorff's reagent (alkaloids) (Harborne 1980).

\section{RESULTS AND DISCUSSION}

The concentrations of the crude plant extracts that inhibited the enzyme activity by $50 \%\left(\mathrm{IC}_{50}\right)$ are presented in the Table. All results exhibited a correlation coefficient of $\mathrm{r}^{2}>0.9$. From the 27 methanol extracts evaluated only $14.81 \%$ showed strong to moderate AChE inhibitory activities.

The strongest AChE inhibitory activities were exhibited by the methanol extracts of Schistocarpha sinforosi Cuatrec. $\left(\mathrm{IC}_{50}=145.31 \mathrm{mg} / \mathrm{l}\right)$ (Asteraceae), Solanum leucocarpum Dunal $\left(\mathrm{IC}_{50}=204.59 \mathrm{mg} / \mathrm{l}\right)$, and Witheringia coccoloboides (Damm.) Hunz $\left(\mathrm{IC}_{50}=220.68 \mathrm{mg} / \mathrm{l}\right)$, both last species belonging to Solanaceae family and Chromolaena tequendamensis (Hieron) R.M. King \& H. Rda. $\left(\mathrm{IC}_{50}=359.36 \mathrm{mg} / \mathrm{l}\right)$ (Asteraceae). However, the phytochemical analysis on the methanol extracts in both Asteraceae species showed the presence of polyphenols, which can generate false-positives effects (Salles et al. 2003). In addition, the evaluation of all species selected for this study by using the AChE inhibition in the TLC assay based on Ellman's method, showed that $S$. sinforosi and $C$. tequendamensis exhibited activities of false-posi-

TABLE

In vitro inhibition of acetylcholinesterase and phytochemical screening of 27 crude methanolic plant extracts from Colombian flora

\begin{tabular}{|c|c|c|c|c|c|c|}
\hline Family & Species (Voucher no.) & $\mathrm{IC}_{50}(\mathrm{mg} / \mathrm{l})$ & Alkaloids & Sterols & Saponins & Polyphenols \\
\hline Asteraceae & $\begin{array}{l}\text { Chromolaena tequendamensis (Hieron) } \\
\text { R.M. King y H. Rda. (FJR 3730) }\end{array}$ & 359.36 & - & - & - & ++ \\
\hline Asteraceae & Liabum asclepiadeum Sch. Bip. (FJR 3720) & $>1000$ & - & + & + & - \\
\hline Asteraceae & Montanoa sp. (FJR 3749) & $>1000$ & - & + & - & + \\
\hline Asteraceae & Munnozia senecionidis Benth. (FJR 3721) & $>1000$ & - & + & + & - \\
\hline Asteraceae & Schistocarpha sinforosi Cuatrec (FJR 3725) & 145.31 & - & - & - & + \\
\hline Asteraceae & Verbesina nudipes Blake (FJR 3746) & $>1000$ & - & + & + & - \\
\hline Euphorbiaceae & Acalypha diversifolia Jacq (FJR 3726) & $>1000$ & + & ++ & ++ & +++ \\
\hline Euphorbiaceae & Acalypha macrostachya Jacq (FJR 3738) & $>1000$ & + & + & ++ & - \\
\hline Euphorbiaceae & Alchornea grandiflora Mûll. Arg (FJR 3727) & $>1000$ & - & ++ & +++ & ++ \\
\hline Melastomataceae & Miconia sp. (FJR 3739) & $>1000$ & - & ++ & - & ++ \\
\hline Rubiaceae & Cinchona pubescens Vahl (FJR 3161) & $>1000$ & + & - & - & - \\
\hline Rubiaceae & Diocidendron dioicum Steyem (FJR 3748) & $>1000$ & - & - & - & + \\
\hline Rubiaceae & Gonzalagunia rosea Standl (FJR 3731) & $>1000$ & - & - & ++ & ++ \\
\hline Rubiaceae & Hoffmannia asperula Standl (FJR 3169) & $>1000$ & + & + & + & + \\
\hline Rubiaceae & Palicourea andaluciana Standl (FJR 3183) & $>1000$ & + & + & + & + \\
\hline Rubiaceae & Palicourea petiolaris Wemh (FJR 3182) & $>1000$ & + & + & + & + \\
\hline Solanaceae & Cestrum olivaceum (FJR 3159) & $>1000$ & - & + & - & + \\
\hline Solanaceae & Deprea glabra (Standl.) A.T. Hunz (FJR 3722) & $>1000$ & - & - & - & - \\
\hline Solanaceae & Lycianthes sp. (FJR 3735) & $>1000$ & + & - & - & + \\
\hline Solanaceae & Lycianthes acutifolia (R y P) (FJR 3156) & $>1000$ & ++ & + & + & - \\
\hline Solanaceae & Lycianthes radiata (Sendt) (FJR 3154) & $>1000$ & ++ & - & - & + \\
\hline Solanaceae & Solanum aphyodendron S. Knapp. (FJR 3729) & $>1000$ & + & - & - & + \\
\hline Solanaceae & Solanum lepidotum Dunal (FJR 3728) & $>1000$ & + & - & - & + \\
\hline Solanaceae & Solanum leucocarpum Dunal (FJR 3717) & 204.59 & +++ & - & - & + \\
\hline Solanaceae & Solanum ovalifoliun Dunal (FJR 3714) & $>1000$ & + & - & - & + \\
\hline Solanaceae & Solanum sycophanta Dunal (FJR 3737) & $>1000$ & + & - & - & + \\
\hline Solanaceae & Witheringia coccoloboides (Damm.) Hunz (FJR 3155) & 220.68 & +++ & ++ & ++ & - \\
\hline Eserine $(2.75 \mathrm{mg} / \mathrm{l})$ & & $\begin{array}{l}100 \% \\
\text { inhibition }\end{array}$ & & & & \\
\hline
\end{tabular}

-: absent; +: weak content; ++: moderate content; +++: strong content. 
tives (data not shown) which can be attributed to the presence of aldehydes on the methanol extracts of these species (Rhee et al. 2003, Mosquera et al. 2004b). Therefore, the true AChE inhibitory activity in this work was displayed mainly by both species belonging to the Solanaceae family.

In general, in the Solanaceae family there has been reported many species with strong AChE inhibitory properties, such is the case of Withania somnifera where three withanolides showed AChE activity (Choudhary et al. 2004). In addition, according to Roddick (1989), the inhibitory effects of the steroidal glycoalkaloids $\alpha$-solanine and $\alpha$-chaconine on human AChE, showed that both alkaloids were equally active and no synergism occurred between the two compounds. On the other hand, $\alpha$-solanine and $\alpha$-chaconine, displayed stronger AChE inhibitory activity than the glycoalkaloids solasonine and solamargine, although they share the same trioside carbohydrate moieties. This confirms the importance of the aglycone moiety structure and evidence the fact that heterocyclic nitrogen of steroidal alkaloids plays an important feature on AChE inhibition.

The AChE inhibitory activities of $S$. leucocarpum Dunal and W. coccoloboides Damm. have never been reported before and their inhibitory AChE activities could be attributed to their high alkaloidal contents (see Table); this correlates with the statement established by Roddick (1989), since their AChE inhibitory activity, could be due to the presence of steroidal glycoalkaloids, which are characteristic to the Solanaceae family.

The Solanaceae, S. leucocarpum and W. coccoloboides showed the highest AChE inhibitory activity in this study, making these two species an important target for the isolation and characterization of the phytocompounds responsible for this biological activity. This fact, confirms that the flora from RNPU has a high potential for the discovery of new and valuable compounds with diverse grade of pharmaceutical applications.

\section{ACKNOWLEDGMENTS}

To Corporación Autónoma Regional de Risaralda for permission to plant collection.

\section{REFERENCES}

Ahmad VU, Khan A, Farooq U, Kousar F, Khan SS, Nawaz SA, Abbasi MA, Choudhary MI 2005. Three new cholinesterase-inhibiting cis-clerodane diterpenoids from Otostegia limbata. Chem Pharm Bull 53: 378-381.

Ahmad W, Ahmad B, Ahmad M, Iqbal Z, Nisar M, Ahmad M 2003a. In vitro inhibition of acetylcholinesterase, butyrylcholinesterase and lipoxygenase by crude extract of Myricaria elegans Royle. J Biol Sci 11: 1046-1049.

Ahmad I, Anis I, Malik A, Nawas AS, Choudhary MI 2003b. Cholinesterase inhibitory constituents from Onosma hispida. Chem Pharm Bull 51: 412-414.

Atta-ur-Rahman, Akhtar MN, Choudhary MI, Tsuda Y, Sener B, Khalid A, Parvez M 2002. New steroidal alkaloids from Fritillaria imperiales and their cholinesterase inhibiting activities. Chem Pharm Bull 50: 1013-1016.
Atta-ur-Rahman, Wahab AT, Nawas SA, Choudhary MI 2004. New cholinesterase inhibiting bisbenzylisoquinoline alkaloids from Cocculus pendulus. Chem Pharm Bull 52: 802-806.

Choudhary MI, Yousuf S, Nawas SA, Ahmed S, Atta-ur-Rahman 2004. Cholinesterase inhibiting withanolides from Withania somnifera. Chem Pharm Bull 52: 1358-1361.

Ellman GL, Courtney D, Andres V, Featherston RM 1961. A new and rapid colorimetric determination of acetylcholinesterase activity. Biochem Pharmacol 7: 88-95.

Ferheen S, Ahmed E, Afza N, Malik A, Shan MR, Nawas SA, Choudhary MI 2005. Haloxylines A and B, antifungal and cholinesterase inhibiting piperidine alkaloids from Haloxylon salicornicum. Chem Pharm Bull 53: 570-572.

Harborne JB 1980. Phytochemical Methods -A Guide to Modern Techniques of Plant Analysis, Chapman and Hall, London, $278 \mathrm{pp}$.

Houghton PJ, Agbedahunsi JM, Adegbulugbe A 2004. Choline esterase inhibitory properties of alkaloids from two Nigerian Crinum species. Phytochemistry 65: 2893-2896.

Kalauni SK, Choudhary MI, Khalid A, Manandhar MD, Shaheen F, Atta-ur-Rahman, Gewali MB 2002. New cholinesterase inhibiting steroidal alkaloids from the leaves of Sarcococca coriacea of Nepalese origin. Chem Pharm Bull 50: 14231426.

Mosquera OM, Correa YM, Niño J 2004a. Antibacterial activity of some Andean Colombian plants. Pharm Biol 42: 499-503.

Mosquera OM, Niño J, Correa YM, Hernádez JA 2004b. Detección in-vitro de inhibidores de la acetilcolinesterasa en extractos crudos de cuarenta plantas de la flora Colombina mediante el método cromátográfico de Ellman. Scientia et Technica 26: 155-160.

Niño J, Correa YM, Mosquera OM 2006. Antibacterial, antifungal and cytotoxic activities from eleven Solanaceae plants from Colombian flora. Pharm Biol 44: 14-18.

Niño J, Espinal CM, Mosquera OM, Correa YM 2003. Antimycotic activity of 20 plants from Colombian flora. Pharm Biol 41: 491-496.

Rhee IK, Appels N, Hofte B, Karabatak B, Erkelens C, Stark LM, Flippin LA, Verpoorte R 2004. Isolation of the acetylcholinesterase inhibitor ungeremine from Nerine bowdenii by preparative HPLC coupled on-line to a flow assay system. Biol Pharm Bull 27: 1804-1809.

Rhee IK, van Rijn RM, Verpoorte R 2003. Qualitative determination of false-positive in the acetylcholinesterase assay using thin layer chromatography. Phytochem Anal 14: 127-131.

Roddick JG 1989. The acetylcholinesterase inhibitory activity of steroidal glycoalkaloids and their aglycones. Phytochemistry 28: 2631-2634.

Salles MT, Viana FV, van de Meent M, Rhee IK, Verpoorte R 2003. Screening for acetylcholinesterase inhibitors from plants to treat Alzheimer disease. Química Nova 26: 1-7.

Sung SY, Kang SY, Lee KY, Park MJ, Kim JH, Park JH, Kim YC, Kim J, Kim YC 2002. (+)- $\alpha$-Viniferin, a stilbene trimer from Caranga chamlague inhibits acetylcholinesterase. Biol Pharm Bull 25: 125-127. 